Pure Appl. Chem., Vol. 85, No. 12, pp. 2161-2174, 2013.

http://dx.doi.org/10.1351/PAC-CON-12-09-05

(C) 2013 IUPAC, Publication date (Web): 2 April 2013

\title{
Effects of ZnO nanoparticles in alfalfa, tomato, and cucumber at the germination stage: Root development and X-ray absorption spectroscopy studies*
}

\author{
Guadalupe de la Rosa1,7, Martha Laura López-Moreno², \\ David de Haro ${ }^{3}$, Cristian E. Botez ${ }^{4}$, José R. Peralta-Videa ${ }^{5,7}$, and \\ Jorge L. Gardea-Torresdey $5,6,7, \ddagger$
}

${ }^{1}$ Division of Science and Engineering, University of Guanajuato, Loma del Bosque 103, Col. Lomas del Campestre, C.P. 37150, Guanajuato, Gto., Mexico; ${ }^{2}$ University of Puerto Rico at Mayagüez, P.O. Box 9019, Mayagüez 00681-901, Puerto Rico; ${ }^{3}$ Department of Chemical Engineering, University of Guanajuato, Col. N. Alta s $/ \mathrm{n}$, C.P. 36050 Guanajuato, Gto., Mexico; ${ }^{4}$ Department of Physics, The University of Texas at El Paso, 500 W. University Ave., El Paso, TX 79968, USA; ${ }^{5}$ Environmental Science and Engineering Ph.D. Program, The University of Texas at El Paso, 500 W. University Ave., El Paso, TX 79968, USA; ${ }^{6}$ Department of Chemistry, The University of Texas at El Paso, 500 W. University Ave., El Paso, TX 79968, USA; ${ }^{7}$ University of California Center for Environmental Implications of Nanotechnology (UC CEIN), USA

\begin{abstract}
Past reports indicate that some nanoparticles (NPs) affect seed germination; however, the biotransformation of metal NPs is still not well understood. This study investigated the toxicity on seed germination/root elongation and the uptake of $\mathrm{ZnO} N P$ s and $\mathrm{Zn}^{2+}$ in alfalfa (Medicago sativa), cucumber (Cucumis sativus), and tomato (Solanum lycopersicum) seedlings. Seeds were treated with ZnO NPs at 0-1600 $\mathrm{mg} \mathrm{L}^{-1}$ as well as $0-250 \mathrm{mg} \mathrm{L}^{-1} \mathrm{Zn}^{2+}$ for comparison purposes. Results showed that at $1600 \mathrm{mg} \mathrm{L}^{-1} \mathrm{ZnO}$ NPs, germination in cucumber increased by $10 \%$, and alfalfa and tomato germination were reduced by 40 and

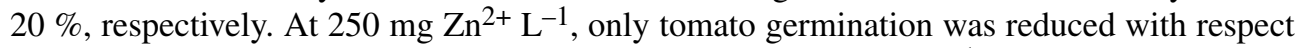
to controls. The highest $\mathrm{Zn}$ content was of 4700 and $3500 \mathrm{mg} \mathrm{kg}^{-1}$ dry weight (DW), for alfalfa seedlings germinated in $1600 \mathrm{mg} \mathrm{L}^{-1} \mathrm{ZnO}$ NPs and $250 \mathrm{mg} \mathrm{L}^{-1} \mathrm{Zn}^{2+}$, respectively. Bulk X-ray absorption spectroscopy (XAS) results indicated that ZnO NPs were probably biotransformed by plants. The edge energy positions of NP-treated samples were at the same position as $\mathrm{Zn}\left(\mathrm{NO}_{3}\right)_{2}$, which indicated that $\mathrm{Zn}$ in all plant species was as $\mathrm{Zn}(\mathrm{II})$.
\end{abstract}

Keywords: absorption; nanoparticles; optical emission spectroscopy; speciation; X-ray absorption spectroscopy (XAS).

*Pure Appl. Chem. 85, 2145-2248 (2013). A collection of invited papers based on presentations at the African Network of Analytical Chemists (SEANAC) $4^{\text {th }}$ Analytical Chemistry Conference, Maputo, Mozambique, 8-11 July 2012.

‡Corresponding author: E-mail: jgardea@utep.edu 


\section{INTRODUCTION}

Nanoparticles (NPs) are unit materials with at least two dimensions, smaller than $100 \mathrm{~nm}$ [1]. Nanotechnology, the study and application of NPs, has rapidly grown in the last few years. Applications for NPs are found in a wide variety of disciplines, including medicine, biology, electronics, and engineering. Intensive research, focused on improving and finding new applications for $\mathrm{ZnO} \mathrm{NPs}$, has highlighted the importance of these materials. Recent reports indicate that ZnO NPs are potentially applicable in the field of bioimaging [2] and in the production of printable electronic devices [3]. These NPs may also be an option for the production of antimicrobial textiles [4], and they have potential application in nanomedicine for the treatment of cancer (NPs preferentially killed cancerous cells) [5]. However, information on the fate, transport, and toxicology of NPs in the environment and human health is still scarce.

To properly understand the effects of these materials in the environment, an interdisciplinary approach is needed [6]. To solve this issue, new scientific fields such as nanotoxicology and nanoecotoxicology have emerged $[7,8]$. Studies performed at the cell level in bacteria and human cell cultures have determined the toxicity of several nanomaterials. It has been reported that $\mathrm{ZnO}$ provoked a cytotoxic response in macrophage and epithelial cells, while $\mathrm{CeO}_{2}$ favored cellular resistance [9]. Recently, Wang et al. [10] observed severe damage in liver and lungs of rats exposed by inhalation to $\mathrm{Fe}_{2} \mathrm{O}_{3}$ and ZnO NPs. Additional reports have described the toxicity of NPs in different living systems, including microalgae [11], nematodes [12], and aquatic organisms [13], among others. With regard to plants, Lin and Xing [14] reported the inhibition of root growth in radish, rape, ryegrass, lettuce, corn, and cucumbers by NPs of aluminum, alumina, zinc, and zinc oxide, and carbon nanotubes. Lee et al. [15] found that $\mathrm{Cu}$ NPs reduced growth and produced necrosis in mung bean (Vigna radiata) and wheat. The nanophytotoxicity of $\mathrm{ZnO}(20 \mathrm{~nm})$ has also been investigated in ryegrass, which displayed a high vacuolation and biomass reduction in the presence of this nanomaterial [16]. Boonyanitipong et al. [17] demonstrated that $\mathrm{ZnO}$ NPs reduced root development in Oryza sativa. However, very little research has been directed to determine the biotransformation of metal NPs in plants. Understanding biotransformation is extremely important to know how NPs change as they are in contact with living organisms and the environment. Mainly with the use of synchrotron techniques, it has been possible to determine that NPs behave differently. Ceria $\left(\mathrm{CeO}_{2}\right) \mathrm{NPs}$ were found untransformed in alfalfa (Medicago sativa), corn (Zea mays), cucumber (Cucumis sativus), and tomato (Lycopersicon esculentum) [18]. On the other hand, NPs were not detected in Prosopis juliflora-velutina, Salsola tragus, and Parkinsonia florida germinated in $\mathrm{ZnO}$ NPs [19].

The aim of this research was to determine the phytotoxicity and uptake of commercial ZnO NPs and the $\mathrm{Zn}^{2+}$ ions in three edible plant species: alfalfa (M. sativa), tomato (L. esculentum), and cucumber (C. sativus). Bulk X-ray absorption spectroscopy (XAS) experiments were performed in order to determine the possible $\mathrm{ZnO}$ and $\mathrm{Zn}^{2+}$ biotransformation in plant tissues. NPs with a particle size less than $10 \mathrm{~nm}$ were selected for this study. Tomato and cucumber are recommended by the U.S. Environmental Protection Agency (EPA) to perform seed germination/root elongation toxicity tests. Alfalfa was included because it is very important forage in the southwestern United States and northern Mexico and because it is a plant profusely studied by several research groups.

\section{MATERIALS AND METHODS}

\section{NP characterization}

The ZnO NPs (Meliorum Technologies, Rochester, NY) were obtained from the University of California Center for Environmental Implications of Nanotechnology (UC-CEIN). For purity determination, $100 \mathrm{mg}$ of NPs was digested in a microwave oven using a mixture of plasma pure $\mathrm{HNO}_{3}+\mathrm{HCl}$ (1:1) as per Xie et al. [20]. Subsequently, the concentration of $\mathrm{Zn}$ in the digested samples was determined using inductively coupled plasma-optical emission spectrometry (ICP-OES) (Perkin Elmer 
Optima 4300 DV, Shelton, CT). X-ray diffraction (XRD) experiments, aimed at phase identification and particle size determination, were carried out using a Siemens D5000 diffractometer equipped with an MBraun position sensitive detector. Powder diffraction patterns corresponding to a $20-60^{\circ} 2 \theta$ range $(\lambda=1.5406 \AA)$ were recorded in the reflectivity geometry. The data collection time for each XRD pattern was approximately $90 \mathrm{~min}$.

\section{Preparation of $\mathrm{ZnO}$ suspensions and determination of $\mathrm{Zn}^{2+}$ concentration}

Suspensions of $\mathrm{ZnO}$ NPs at the following concentrations were prepared: 0, 50, 100, 200, 400, 800, and $1600 \mathrm{mg} \mathrm{L}^{-1}$. The suspensions were sonicated for $30 \mathrm{~min}$ to avoid aggregation according to Lin and Xing [14]. In order to determine the concentrations of $\mathrm{Zn}^{2+}$, the procedure reported by Ling and Xing [14] was followed with only minimum modifications. Briefly, suspensions were centrifuged for $1 \mathrm{~h}$ at 4000 rpm (Fisher Scientific 8K, Houston, TX) and filtered through 551 Whatman Schleicher \& Schuell filters (Sigma-Aldrich, St. Louis, MO). Concentrations of $\mathrm{Zn}$ found in the supernatants were used as reference for the $\mathrm{Zn}^{2+}$ treatments (selected concentrations were $0,0.05,0.5,5,10,50$, and $250 \mathrm{mg} \mathrm{Zn}^{2+}$ $\left.\mathrm{L}^{-1}\right)$ that were prepared from $\mathrm{Zn}\left(\mathrm{NO}_{3}\right)_{2}$.

\section{Germination experiments}

Seeds of tomato (L. esculentum, Roma FV; Western Seeds International, El Centro, CA), cucumber (C. sativus, Poinsett 76; Western Seeds International, El Centro, CA), and alfalfa (M. sativa, WL535; Del Norte Seed \& Feed, El Paso, TX) were used in this study. Seeds were treated for 30 min with a $4 \%$ $\mathrm{NaClO}$ solution for disinfection, followed by rinsing with sterilized Millipore water (MPW). Germination paper (Nasco, Fort Atkinson, WI) cut to fit regular Petri dishes was used as inert material. A piece of germination paper was placed on the bottom of the Petri dish, and $5 \mathrm{~mL}$ of $\mathrm{ZnO}$ or $\mathrm{Zn}^{2+}$, at the appropriate concentrations, was added [14]. Thirty seeds of each species were placed in every Petri dish, covered with a second germination paper piece, dampened with 10 drops of an antibiotic-antimycotic solution (Sigma A5955, Sigma, St. Louis, MO), and covered. Aluminum paper was used to protect seeds from light, and the treated seeds were placed in a growth chamber at $20{ }^{\circ} \mathrm{C}$. The germination was evaluated when approximately $65 \%$ of the control roots were at least $5 \mathrm{~mm}$ long [21]. To eliminate any surface metal, the seedlings were rinsed first with $0.01 \mathrm{M} \mathrm{HNO}_{3}$ and later with MPW. Roots and stems of 10 seedlings per replicate were measured and dried in an oven at $70{ }^{\circ} \mathrm{C}$ for two days. Average weight was calculated on a 10-seedling basis.

\section{Quantification of $\mathrm{Zn}$ in dry plant tissues}

Plant tissues were digested in a CEM microwave oven (CEM Corporation, Mathews, NC) following the EPA 3051 method [22] using $3 \mathrm{~mL}$ of plasma pure $\mathrm{HNO}_{3}$. The digested samples were diluted to $25 \mathrm{~mL}$ with MPW and read on the ICP-OES. A blank and a standard were read every 10 samples for quality control/quality assurance (QC/QA) purposes.

\section{Statistical analysis and quality control}

Three replicates per treatment with 30 seeds per replicate were set up for the experiments following a completely random design. Standard reference material 1570a (spinach leaves) was used to validate the digestion and analytical method. Spikes were used to determine the percent recovery of Zn. Data was reported as mean \pm standard error (SE), and a one-way ANOVA analysis (SPSS 13.0 package) was followed by the Tukey's multiple comparison test. 


\section{XAS experiments}

A portion of seedlings treated with $1600 \mathrm{mg} \mathrm{ZnO} \mathrm{NPs} \mathrm{L}^{-1}$ and $250 \mathrm{mg} \mathrm{Zn}^{2+} \mathrm{L}^{-1}$ was frozen in liquid nitrogen and lyophilized in a Labconco FreeZone 4.5 freeze-dryer (Kansas City, MO) at $-53{ }^{\circ} \mathrm{C}$ and $0.140 \mathrm{mBar}$ pressure for three days. Powdered dry tissues were placed on aluminum sample holders and covered with Mylar ${ }^{\odot}$ tape. The XAS spectra of plant samples, ZnO NPs, and Zn nitrate were collected at beam line 7-3 at the Stanford Synchrotron Radiation Laboratory (SSRL). Fluorescence spectra for Zn edge were obtained using a Canberra 29-element array germanium detector (Meriden, CT) by monitoring the $\mathrm{Zn} \mathrm{K}$. The standard operating conditions of the beam line were $3 \mathrm{GeV}$ beam energy, a 50-100 mA beam current, and a $\operatorname{Si}(220) \varphi 90$ monochromator. Spectra from samples were calibrated with the spectrum from a $\mathrm{Zn}$ foil at the time of data collection.

The data analysis was done using the WinXAS software [23]. The edge energy was calibrated using the edge position of an internal $\mathrm{Zn}$ foil with edge energy of $9659 \mathrm{eV}$. The calibration of the sample spectrum was performed using first- and second-degree derivatives of the inflection point of the $\mathrm{Zn}$ foil. A polynomial fitting subtraction was used to remove background. A first-degree polynomial was used on the pre-edge region and a fourth-degree polynomial was used on the post-edge region of the spectrum. The conversion into $\mathrm{k}$ space was based on the energy of the photoelectrons ejected from the samples. Kinetic energy of the photoelectrons ejected was calculated based on the $\mathrm{Zn}$ edge position and converted into wave vector space ( $\mathrm{k}$ space). The resulting scattering curves were then $\mathrm{k}$ weighted to three in order to enhance dampened scattering oscillations and Fourier transformation into interatomic distance space. The coordination numbers and the Debye-Waller factors were obtained by least-squares fitting of the extended X-ray absorption fine structure (EXAFS) data using FEFF800 [24]. The spectra of $\mathrm{Zn}$-seedling samples were fitted to the EXAFS spectra of the model compounds that best matched the samples.

\section{RESULTS AND DISCUSSION}

\section{$\mathrm{ZnO}$ NP characterization and determination of $\mathrm{Zn}^{2+}$ ions in $\mathrm{ZnO}$ NP suspensions}

XRD analyses showed no impurities in any of the ZnO NP samples used in this study. The average particle size was determined from the full width at half maximum (FWHM) of the (110) Bragg peak using the Scherrer equation [25], where the FWHM was obtained from the best fit of the peak profile to a combination of Gaussian and Lorentzian functions. This analysis yielded an average particle size of $8 \mathrm{~nm}$. The ICP analyses indicated a purity of $100.3 \% \pm 3$. The detection limit for $\mathrm{Zn}$ was $0.018 \mathrm{mg} \mathrm{L}^{-1}$ and percent recovery was $98 \%$. The $\mathrm{Zn}^{2+}$ concentrations in 50, 100, 200, 400, 800, and $1600 \mathrm{mg} \mathrm{L}^{-1}$ $\mathrm{ZnO}$ NP suspensions were of 3.2, 7.2, 9.6, 17.2, 25.6, and $24.17 \mathrm{mg} \mathrm{L}^{-1}$, respectively. These concentrations were used as reference for experiments aimed to determine the phytotoxicity of $\mathrm{Zn}$ ions. The NP solubility and release of metal ions are significant factors in establishing the fate and transport of nanomaterials in living organisms $[11,26]$.

\section{Effect of $\mathrm{ZnO}$ NPs and $\mathrm{Zn}^{2+}$ on seed germination}

Seed germination percentage has been used to evaluate the toxicity of metals and metalloids in several plant species [27]. In this study, seed germination and root elongation were evaluated when $65 \%$ of the total seeds were germinated and root elongation was more than $0.5 \mathrm{~mm}$ [21]. The germination percentage for alfalfa, tomato, and cucumber seeds soaked in $0,50,100,200,400,800$, and $1600 \mathrm{mg} \mathrm{L}^{-1}$ of $\mathrm{ZnO}$ NPs is shown in Fig. 1A. With the exception of the controls and treatment of $1600 \mathrm{mg} \mathrm{L}^{-1} \mathrm{ZnO}$, alfalfa seed germination followed a bell-shape trend (Fig. 1Aa). As compared to control, only 800 and $1600 \mathrm{mg} \mathrm{L}^{-1}$ of $\mathrm{ZnO}$ NPs caused a significant reduction in alfalfa germination (40\%). However, even when not significantly different from control, $50 \mathrm{mg} \mathrm{L}^{-1} \mathrm{ZnO}$ NPs reduced this parameter in a $25 \%$. It has been proven that different nanomaterials are able to produce dissimilar effects on seed germination. 
(A)

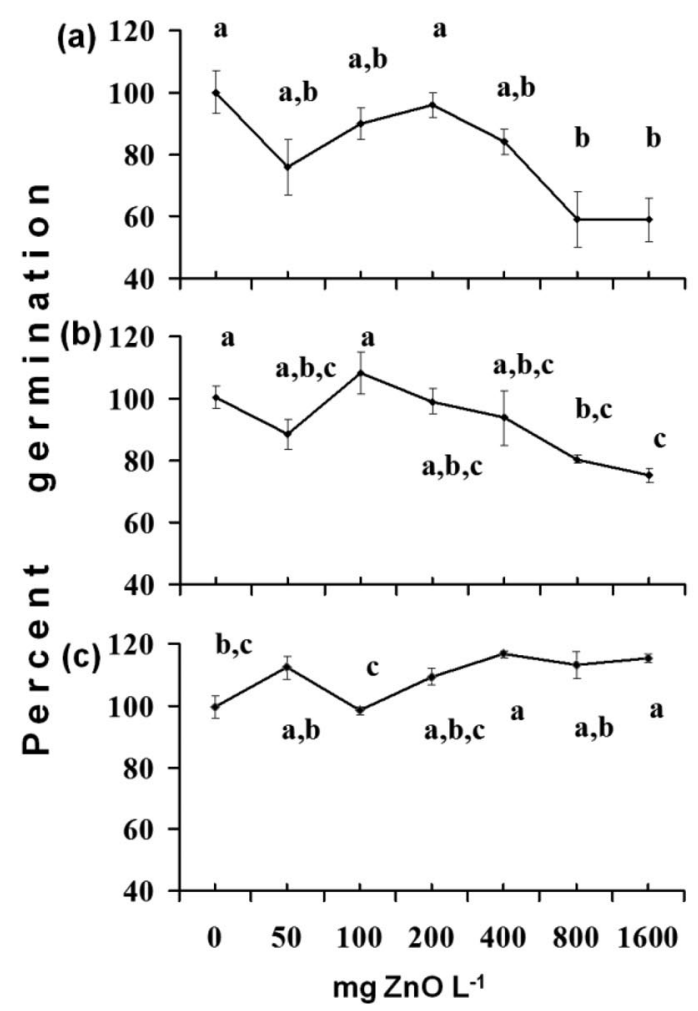

(B)
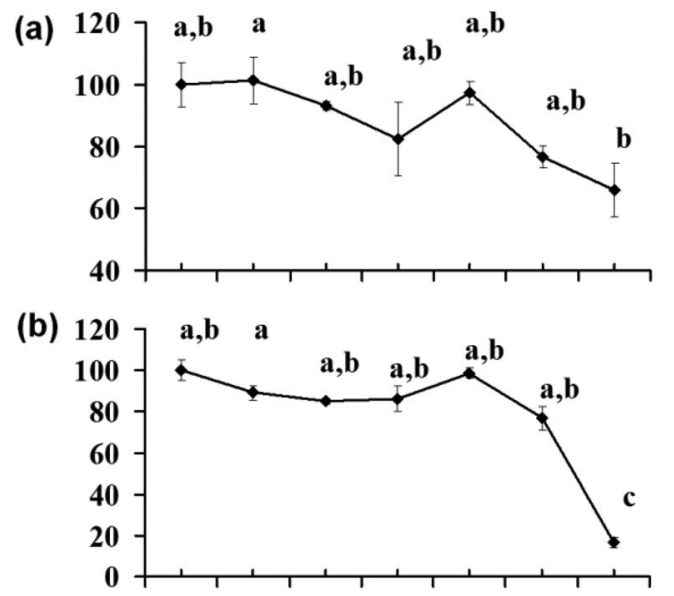

(c)

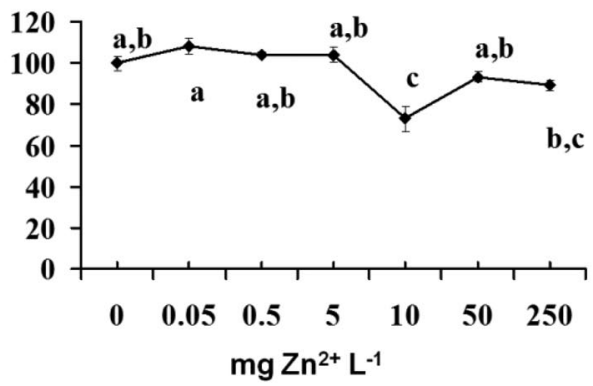

Fig. 1 Percent germination of (a) alfalfa, (b) tomato, and (c) cucumber seeds treated with (A) $0-1600 \mathrm{mg} \mathrm{L}^{-1} \mathrm{ZnO}$ NPs and (B) $0-250 \mathrm{mg} \mathrm{L}^{-1} \mathrm{Zn}^{2+}$ supplied as $\mathrm{Zn}\left(\mathrm{NO}_{3}\right)_{2}$. Data are means $\pm \mathrm{SE}$ of three replicates. Lowercase letters indicate statistically significant differences at $P<0.05$.

Klaine et al. [28] reported that ZnO NPs can decrease germination percentage in corn seedlings, while $\mathrm{TiO}_{2}$ NPs can stimulate seed germination in spinach seedlings. Tomato seed germination was evaluated after 13 days of treatment (Fig. 1Ab). No significant differences in percent germination (with respect to controls) were found in tomato seeds exposed to $\mathrm{ZnO}$ concentrations between 50 and $400 \mathrm{mg} \mathrm{L}^{-1}$ (Fig. $1 \mathrm{Ab}$ ). However, approximately a $20 \%$ germination reduction was observed in tomatoes treated with $1600 \mathrm{mg} \mathrm{L}^{-1}$ of ZnO NPs. On the other hand, as shown in Fig. 1Ac, the percent germination of cucumber showed a significant increase in $\mathrm{ZnO}$ levels of 400 and $1600 \mathrm{mg} \mathrm{L}^{-1}$, as compared to controls. In this case, germination was determined after 12 days of exposure. Up to now, it is unknown if the $\mathrm{ZnO}$ NPs interfere with the production of gibberellins, a phytohormone that promotes seed germination. The results of the present study differ from those reported by Lin and Xing [14], who found that $2000 \mathrm{mg}$ $\mathrm{L}^{-1}$ of $20 \mathrm{~nm} \mathrm{ZnO}$ NPs did not affect germination of cucumber. This suggests that the difference in NP size plays a role in phytotoxicity; however, varietal differences could also drive the results.

Several reports indicate that NP type and solubility are important factors related to the toxicity in plants [11,29]. In addition, Brunner et al. [30] stated that NP solubility plays an important role in the toxicity of metal oxide nanomaterials in human mesothelioma and in rodent fibroblast cells. They found that both cell cultures (human MSTO-211H and rodent $3 \mathrm{~T} 3$ cells) died when treated with $15 \mathrm{mg} \mathrm{L}^{-1}$ of $\mathrm{ZnO}$. However, the same cell cultures were not affected by tricalcium phosphate NPs at this same concentration. 
In order to determine the role of the dissociated $\mathrm{Zn}^{2+}$ ions in the toxicity of $\mathrm{ZnO} \mathrm{NPs}$, the quantification of $\mathrm{Zn}^{2+}$ was performed in all $\mathrm{ZnO} N P$ suspensions. $\mathrm{Zn}^{2+}$ concentrations were found in a range between 3.0 and $25 \mathrm{mg} \mathrm{L}^{-1}$. Based on these findings, selected concentrations for seed exposure were of $0,0.05,0.5,5,10,50$, and $250 \mathrm{mg} \mathrm{L}^{-1} \mathrm{Zn}^{2+}$. These were chosen in order to include at least one order of magnitude to the left and right of the minimum and maximum $\mathrm{Zn}^{2+}$ concentration value determined in the suspensions.

The results for the germination of the plant species treated with $\mathrm{Zn}^{2+}$ ions are shown in Fig. 1B. The $\mathrm{pH}$ of $\mathrm{Zn}\left(\mathrm{NO}_{3}\right)_{2}$ solutions was adjusted to the same $\mathrm{pH}$ as that of $\mathrm{ZnO} \mathrm{NP}$ suspensions $(\mathrm{pH}=$ $7.0 \pm 0.1)$. A $40 \%$ reduction in germination reduction was observed in alfalfa seeds treated with 50 and $250 \mathrm{mg} \mathrm{L}^{-1}$ of $\mathrm{Zn}^{2+}$ (Fig. 1Ba). However, no statistical difference was observed. A slight increase in alfalfa germination was observed at $0.05 \mathrm{mg} \mathrm{L}^{-1}$ of $\mathrm{Zn}^{2+}$; however, germination was reduced by $34 \%$ at $250 \mathrm{mg} \mathrm{L}^{-1}$. This value was significantly different from that of the $0.05 \mathrm{mg} \mathrm{Zn}^{2+} \mathrm{L}^{-1}$. Al-Yemeni and Al-Helal [31] have reported a reduction of $30 \%$ in alfalfa germination with $5 \mathrm{mM} \mathrm{ZnCl}_{2} \approx 330 \mathrm{mg}$ $\mathrm{Zn}^{2+} \mathrm{L}^{-1}$ ), which is higher than the concentration used in the present study. The difference could be attributed to dissimilarities in varietal constitution. No significant differences were observed in tomato germination with $\mathrm{Zn}^{2+}$ concentrations between 0 and $50 \mathrm{mg} \mathrm{L}^{-1}$ (Fig. $1 \mathrm{Bb}$ ). However, at $250 \mathrm{mg} \mathrm{L}^{-1}$, a dramatic reduction of $84 \%$ was observed. It has been reported that low $\mathrm{Zn}^{2+}$ concentrations promoted tomato germination [32], although reports indicated that, at certain levels, $\mathrm{Zn}^{2+}$ inhibited aquaporins involved in seed germination [33]. Further experiments can be performed in order to determine if at this $\mathrm{Zn}^{2+}$ concentration, inhibition of germination in tomato was due to the inhibition of aquaporins. Figure 1Bc shows no significant effects on cucumber germination with the exception of the treatment at $10 \mathrm{mg} \mathrm{Zn}{ }^{2+} \mathrm{L}^{-1}$. Ozdener et al. [34] demonstrated that $\mathrm{Zn}^{2+}$ at concentrations up to $1000 \mathrm{mg} \mathrm{L}^{-1}$ did not affect root elongation of Eruca sativa germinated in the $\mathrm{Zn}$ treatment. According to El-Ghamery et al. [35], the effect of metal treatment on seed germination depends on the time of exposure, metal concentrations in the media, and plant species. Alfalfa belongs to the Fabaceae family, while tomato and cucumber correspond to the Solanaceae and Cucurbitaceae families, respectively. Further biochemical and analytical studies may provide a better insight into the nature of plant resistance and tolerance to $\mathrm{ZnO}$ NPs and $\mathrm{Zn}^{2+}$ ions.

\section{Effect of $\mathrm{ZnO} \mathrm{NPs}$ and $\mathrm{Zn}^{2+}$ on root seedling growth}

The effects of $\mathrm{ZnO}$ NPs and $\mathrm{Zn}^{2+}$ ions on root growth of alfalfa, tomato, and cucumber seedlings are presented in Table 1. Inhibitory concentrations of $50 \%\left(\mathrm{IC}_{50}\right)$ were observed in alfalfa and tomato seedlings treated with 800 and $1600 \mathrm{mg} \mathrm{L}^{-1}$ of $\mathrm{ZnO}$ NPs. However, cucumber response to the NPs was positive as hormesis was observed [36]. Seedlings germinated in 200, 400, and $800 \mathrm{mg} \mathrm{L}^{-1}$ of ZnO NPs were 2.7, 1.9, and 1.4 times larger $(P<0.05)$ than control roots, respectively. These results agree with those found by Lin and Xing [14], who reported that $2000 \mathrm{mg} \mathrm{L}^{-1}$ of $\mathrm{ZnO}$ (20 nm in size) affected root growth in radish, rape, ryegrass, and lettuce seedlings raised from seeds previously soaked in NP suspensions. Lin and Xing [14] have stated that toxicity of nanomaterials is due not only to the presence of $\mathrm{ZnO}$ NPs but also to $\mathrm{Zn}^{2+}$ ions released in the media. Cell walls in plants contain small pores ranging from 5-20 nm, which allow for transportation of NPs less than $20 \mathrm{~nm}$ through the cell wall and the bilayer lipid membrane of the plasma membrane [37]. Hitherto, it is not known if the NPs interact with the production of auxins, phytohormones that promote root elongation. Furthermore, since the NPs used in this investigation are smaller than $20 \mathrm{~nm}$, it is very likely that they were able to cross the cell wall; thus, affecting the normal germination and growth process.

A significant decrease (about $30 \%$ ) in alfalfa root length occurred in the treatment of $50 \mathrm{mg} \mathrm{L}$ of $\mathrm{Zn}^{2+}$ (Table 1). In addition, at $250 \mathrm{mg} \mathrm{L}^{-1}$ of $\mathrm{Zn}^{2+}$, the $\mathrm{IC}_{50}$ was observed. Nigella sativa and Triticum aestivum [35] were more sensitive to $\mathrm{Zn}^{2+}$ than the plant species used in the present study, since in those two species $25 \mathrm{mg} \mathrm{L}^{-1}$ of $\mathrm{Zn}^{2+}$ affected root growth. According to Herren and Feller [38] and Atici et 
al. [39], $\mathrm{Zn}$ is an essential element for plant growth but at relatively high concentrations can interfere with several metabolic processes and can also modify the mineral root uptake.

\begin{tabular}{|c|c|c|c|}
\hline $\begin{array}{l}\mathrm{ZnO} \\
\left(\mathrm{mg} \mathrm{L}^{-1}\right)\end{array}$ & $\begin{array}{l}\text { Alfalfa } \\
(\mathrm{cm})\end{array}$ & $\begin{array}{l}\text { Tomato } \\
(\mathrm{cm})\end{array}$ & $\begin{array}{c}\text { Cucumber } \\
(\mathrm{cm})\end{array}$ \\
\hline 0 & $1.5 \pm 0.1 \mathrm{a}$ & $1.0 \pm 0.0 \mathrm{a}$ & $1.7 \pm 0.1 \mathrm{de}$ \\
\hline 50 & $1.2 \pm 0.1 b$ & $0.9 \pm 0.0 \mathrm{a}$ & $1.9 \pm 0.1 \mathrm{~cd}$ \\
\hline 100 & $1.5 \pm 0.1 \mathrm{a}$ & $0.72 \pm 0.1 b c$ & $1.7 \pm 0.1 \mathrm{de}$ \\
\hline 200 & $1.3 \pm 0.1 \mathrm{ab}$ & $0.74 \pm 0.0 \mathrm{~b}$ & $4.6 \pm 0.1 \mathrm{a}$ \\
\hline 400 & $1.2 \pm 0.0 \mathrm{~b}$ & $0.7 \pm 0.0 \mathrm{bcd}$ & $3.3 \pm 0.1 b$ \\
\hline 800 & $0.7 \pm 0.0 \mathrm{c}$ & $0.57 \pm 0.0 \mathrm{~d}$ & $2.3 \pm 0.1 \mathrm{c}$ \\
\hline 1600 & $0.8 \pm 0.0 \mathrm{c}$ & $0.58 \pm 0.0 \mathrm{~cd}$ & $1.5 \pm 0.0 \mathrm{e}$ \\
\hline \multicolumn{4}{|l|}{$\begin{array}{l}\mathrm{Zn}^{2+} \\
\left(\mathrm{mg} \mathrm{L}^{-1}\right)\end{array}$} \\
\hline 0 & $1.6 \pm 0.1 \mathrm{a}$ & $0.9 \pm 0.0 \mathrm{a}$ & $1.7 \pm 1.0 \mathrm{~b}$ \\
\hline 0.05 & $1.6 \pm 0.1 \mathrm{a}$ & $0.9 \pm 0.0 \mathrm{a}$ & $1.8 \pm 1.0 \mathrm{ab}$ \\
\hline 0.5 & $1.6 \pm 0.1 \mathrm{a}$ & $0.8 \pm 0.0 \mathrm{ab}$ & $2.1 \pm 1.0 \mathrm{a}$ \\
\hline 5 & $1.4 \pm 0.1 \mathrm{a}$ & $0.7 \pm 0.0 b$ & $1.9 \pm 1.0 \mathrm{ab}$ \\
\hline 10 & $1.5 \pm 0.1 \mathrm{a}$ & $0.9 \pm 0.1 \mathrm{a}$ & $0.9 \pm 1.0 \mathrm{~d}$ \\
\hline 50 & $1.1 \pm 0.0 \mathrm{~b}$ & $0.7 \pm 0.0 \mathrm{ab}$ & $1.3 \pm 1.0 \mathrm{c}$ \\
\hline 250 & $0.8 \pm 0.0 \mathrm{~b}$ & $0.4 \pm 0.0 \mathrm{c}$ & $1.2 \pm 0.0 \mathrm{~cd}$ \\
\hline
\end{tabular}

*One-way ANOVA and Tukey's test were used to determine statistical significance of the differences between treatment means. The level of significance was at $p \leq 0.05$.

The $\mathrm{IC}_{50}$ in cucumbers was observed in seedlings treated with $10 \mathrm{mg} \mathrm{L}^{-1}$ of $\mathrm{Zn}^{2+}$. However, at higher concentrations ( 50 and $250 \mathrm{mg} \mathrm{L}^{-1} \mathrm{Zn}^{2+}$ ), the root length reduction was less conspicuous since a decrease of 24 and $29 \%$, respectively, was observed. Differences in plant species is the reason for dissimilar Zn uptake, tolerance, and toxicity [40].

\section{Effect of $\mathrm{ZnO}$ NPs and $\mathrm{Zn}^{2+}$ on biomass production}

The DW of 10 seedlings of alfalfa, tomato, and cucumber germinated in ZnO NP concentrations varying from 0 to $1600 \mathrm{mg} \mathrm{L}^{-1}$, and $0-250 \mathrm{mg} \mathrm{L}^{-1} \mathrm{Zn}^{2+}$ is shown in Table 2. It was observed that alfalfa biomass production was not significantly affected by the $\mathrm{ZnO} N P$ levels used in this study, although this species accumulated the most $\mathrm{Zn}$. In tomatoes, seedlings increased the biomass production $(35 \%$ with respect to controls) when seeds were germinated with $800 \mathrm{mg} \mathrm{L}^{-1} \mathrm{ZnO}$ NPs. Cucumber biomass yield displayed a U-shaped response, since concentrations between 100 and $400 \mathrm{mg} \mathrm{L}^{-1}$ of ZnO NPs decreased biomass by about $10 \%$. Lower and higher concentrations tended to increase seedling weight. The increase in biomass and root growth of plants exposed to NPs has also been observed by Gao et al. [41], who reported that single fresh weight and DW of soil-grown spinach plants treated with nanoanatase $\mathrm{TiO}_{2} \mathrm{NPs}$ increased by 60.21 and $70.32 \%$, respectively.

For comparison purposes, the biomass production with $\mathrm{Zn}^{2+}$ ions was recorded. As seen in Table 2, a significant increase in biomass weight was obtained by alfalfa and tomato seedlings treated with $250 \mathrm{mg} \mathrm{L}^{-1} \mathrm{Zn}^{2+}$ (59 and $390 \%$, respectively), as compared to controls. These results differ from those obtained with $\mathrm{ZnO}$ NPs, barring the tomatoes at $800 \mathrm{mg} \mathrm{L}^{-1}$ of NPs. There is no clear explana- 
tion for these results, but it is hypothesized that $\mathrm{Zn}^{2+}$ ions are more readily available towards activating plant genes involved in biomass production. This hypothesis is supported by results found by Puzio et al. [42]. Biomass production in cucumber seedlings was not affected by the different concentrations of $\mathrm{Zn}^{2+}$. These results were similar to the results observed in seedlings treated with the ZnO NPs, which corroborate the differential tolerance of plant species to $\mathrm{Zn}$ and $\mathrm{ZnO}$ NPs.

Table 2 Biomass weight ( $\mathrm{mg}$ ) of 10 seedlings germinated with (a) 0-1600 mg L-1 of ZnO NPs; and (b) $0-250 \mathrm{mg} \mathrm{L}^{-1}$ of $\mathrm{Zn}^{2+}$ supplied as $\mathrm{Zn}\left(\mathrm{NO}_{3}\right)_{2}$.

\begin{tabular}{cccc}
\hline $\begin{array}{l}\mathrm{ZnO} \\
\left(\mathrm{mg} \mathrm{L}^{-1}\right)\end{array}$ & $\begin{array}{c}\text { Alfalfa } \\
(\mathrm{mg})\end{array}$ & $\begin{array}{c}\text { Tomato } \\
(\mathrm{mg})\end{array}$ & $\begin{array}{c}\text { Cucumber } \\
(\mathrm{mg})\end{array}$ \\
\hline 0 & $13.1 \pm 0.3$ & $14.8 \pm 0.8 \mathrm{~b}$ & $19.3 \pm 0.2 \mathrm{a}$ \\
50 & $10.8 \pm 0.9$ & $16.7 \pm 0.5 \mathrm{ab}$ & $17.8 \pm 0.4 \mathrm{ab}$ \\
100 & $13.1 \pm 0.9$ & $17.1 \pm 0.5 \mathrm{ab}$ & $17.1 \pm 0.4 \mathrm{~b}$ \\
200 & $15.1 \pm 0.9$ & $16.3 \pm 1.1 \mathrm{ab}$ & $16.8 \pm 0.2 \mathrm{~b}$ \\
400 & $12.4 \pm 0.5$ & $15.0 \pm 0.4 \mathrm{~b}$ & $17.1 \pm 0.1 \mathrm{~b}$ \\
800 & $10.3 \pm 2.7$ & $20.0 \pm 1.5 \mathrm{a}$ & $17.6 \pm 0.7 \mathrm{ab}$ \\
1600 & $11.8 \pm 1.6$ & $16.9 \pm 0.99 \mathrm{ab}$ & $17.6 \pm 0.4 \mathrm{ab}$ \\
\hline $\mathrm{Zn}^{2+}$ & & & \\
$\left(\mathrm{mg} \mathrm{L}^{-1}\right)$ & & & \\
\hline 0 & $14.4 \pm 1.3 \mathrm{~b}$ & $15.6 \pm 0.2 \mathrm{~b}$ & $19.3 \pm 0.16$ \\
0.05 & $15.5 \pm 0.6 \mathrm{ab}$ & $10.8 \pm 1.7 \mathrm{~b}$ & $19.2 \pm 0.4$ \\
0.5 & $15.3 \pm 0.4 \mathrm{ab}$ & $15.8 \pm 0.6 \mathrm{~b}$ & $18.4 \pm 2.1$ \\
5.0 & $15.0 \pm 0.7 \mathrm{ab}$ & $15.6 \pm 0.6 \mathrm{~b}$ & $18.5 \pm 1.3$ \\
10 & $15.3 \pm 0.9 \mathrm{ab}$ & $18.6 \pm 1.4 \mathrm{~b}$ & $15.5 \pm 3.5$ \\
50 & $16.1 \pm 0.2 \mathrm{ab}$ & $16.2 \pm 0.7 \mathrm{~b}$ & $13.6 \pm 3.6$ \\
250 & $22.9 \pm 4.0 \mathrm{a}$ & $76.7 \pm 14.5 \mathrm{a}$ & $19.8 \pm 0.0$ \\
\hline
\end{tabular}

*One-way ANOVA and Tukey's test were used to determine statistical significance of the differences between treatment means. The level of significance was at $p \leq 0.05$.

\section{Zn uptake by seedlings germinated in ZnO NPs and $\mathrm{Zn}^{2+}$}

Concentrations of $\mathrm{Zn}$ in seedlings grown with $\mathrm{ZnO}$ NPs are shown Fig. 2a. As seen in Fig. 2a, the concentration of $\mathrm{Zn}$ in tissues increased as the external concentration of NPs increased. At $1600 \mathrm{mg} \mathrm{L}^{-1}$ of $\mathrm{NPs}$, the concentration of $\mathrm{Zn}\left(\mathrm{mg} \mathrm{kg}^{-1} \mathrm{DW}\right)$ was: alfalfa $(4700)>$ tomato $(2100)>$ cucumber $(1600)$. The tolerance of diverse species to metal stress causes variations in metal accumulation. As described previously, some of the $\mathrm{ZnO}$ NPs were dissolved in the media to form hydrated $\mathrm{Zn}^{2+}$ cations available for seedling uptake [9]. However, in the present study, the amount of $\mathrm{Zn}^{2+}$ ions released at $1600 \mathrm{mg} \mathrm{L}^{-1}$ of NPs was only $25 \mathrm{mg} \mathrm{Zn} \mathrm{L}{ }^{-1}$. Thus, the most $\mathrm{Zn}$ accumulation came from the NPs. This was corroborated in Fig. 2b, which shows the concentration of $\mathrm{Zn}$ in seedlings germinated with $0-250 \mathrm{mg} \mathrm{L}^{-1}$ of $\mathrm{Zn}^{2+}$. Similar to the results found with the NPs, as the external $\mathrm{Zn}^{+2}$ increased, $\mathrm{Zn}$ levels in tissues increased, thus presenting a concentration order as the one observed in seedlings grown with the NPs. At $250 \mathrm{mg} \mathrm{L}{ }^{-1} \mathrm{Zn}^{2+}$ treatment, the highest $\mathrm{Zn}$ concentration was found in alfalfa ( $3500 \mathrm{mg} \mathrm{Zn} \mathrm{kg} \mathrm{g}^{-1}$ DW) followed by tomato (1100 mg Zn kg-1 DW). Differences in cell wall composition from diverse plant species and genotypes can result in higher or lower uptake of metal ions by plant roots, especially in non-metal hyperaccumulators [43]. 
(a)

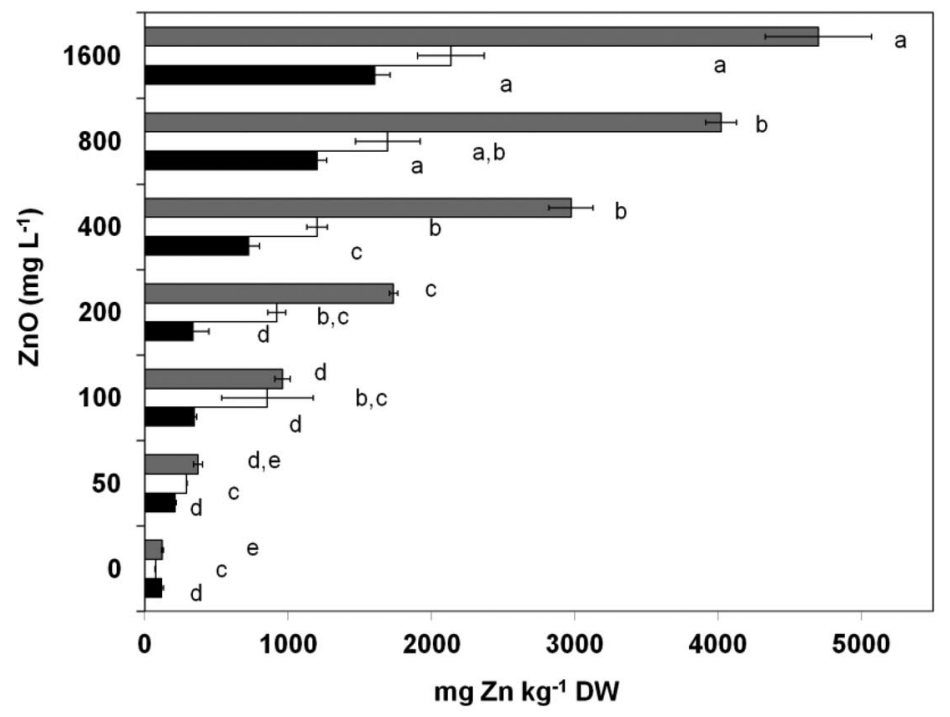

(b)

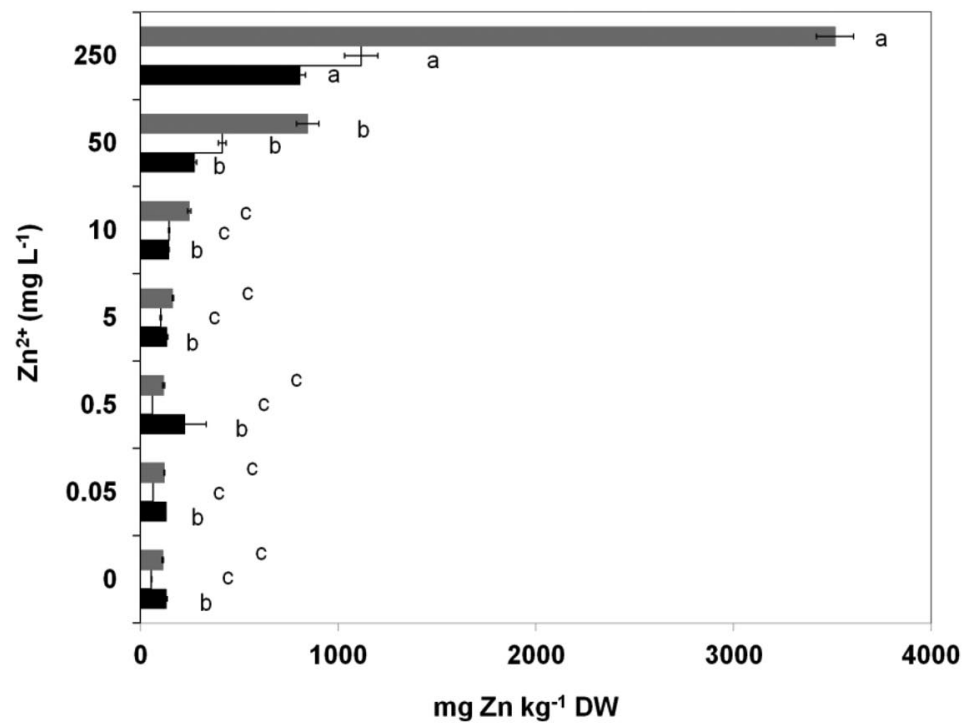

Fig. $2 \mathrm{Zn}$ concentration in $\square$ alfalfa, $\square$ tomato, and $\mathbf{a}$ cucumber seedlings germinated with (a) ZnO NP suspensions (at 0-1600 mg L ${ }^{-1}$ ); and (b) 0-250 $\mathrm{mg} \mathrm{L}^{-1} \mathrm{Zn}^{2+}$ supplied as $\mathrm{Zn}\left(\mathrm{NO}_{3}\right)_{2}$. Data are means of three replicates $\pm \mathrm{SE}$. Lowercase letters indicate statistically significant differences in $\mathrm{Zn}$ content in each plant species at $P \leq 0.05$.

\section{Bulk X-ray absorption near-edge spectroscopy (XANES) results}

Figure 3 shows the characteristic Zn K-edge of XANES spectra from the $\mathrm{ZnO} \mathrm{NPs}, \mathrm{Zn}\left(\mathrm{NO}_{3}\right)_{2}$, and the XANES spectra of plant samples treated with $\mathrm{ZnO}$ NPs and $\mathrm{Zn}^{2+}$. Results showed $\mathrm{Zn} \mathrm{K}$-edge at $9659 \mathrm{eV}$, which corresponds to the electronic transition from the $\mathrm{Zn}$ 1s orbital to the $\mathrm{Zn} 4 \mathrm{p}$ orbital. In addition, XANES spectra of all ZnO NP-treated seedlings indicated that the pre-edge and edge energy positions of samples are at the same position as that of the $\mathrm{Zn}\left(\mathrm{NO}_{3}\right)_{2}$, which indicates that $\mathrm{Zn}$ in all 


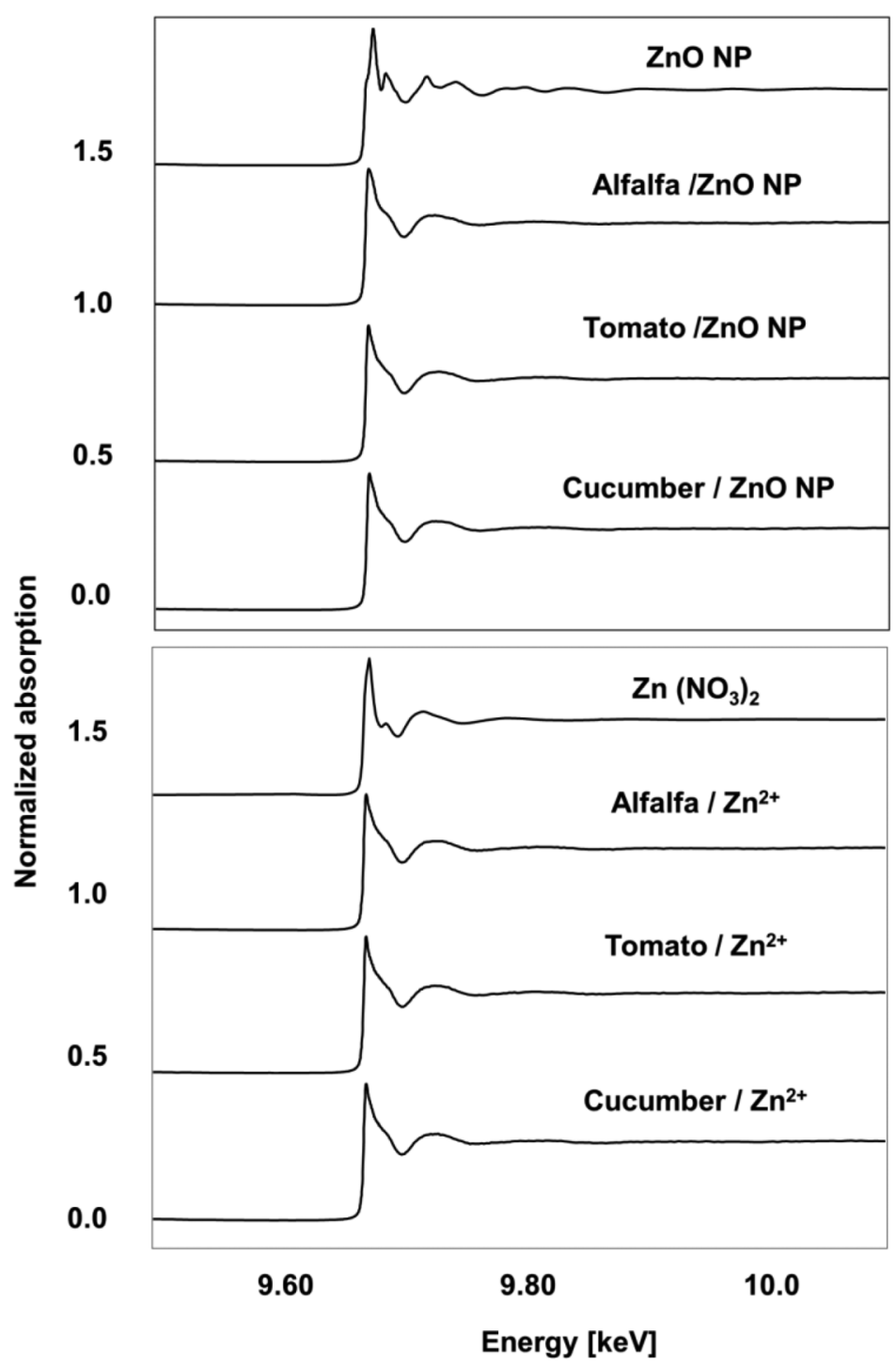

Fig. 3 XANES K-edge spectra $(9659 \mathrm{eV})$ of $\mathrm{ZnO} \mathrm{NPs}, \mathrm{Zn}\left(\mathrm{NO}_{3}\right)_{2}$ model compounds and spectra from alfalfa, tomato, and cucumber seedlings treated with $1600 \mathrm{mg} \mathrm{L}^{-1}$ of $\mathrm{ZnO} \mathrm{NPs}$ and $250 \mathrm{mg} \mathrm{L}^{-1}$ of $\mathrm{Zn}^{2+}$ supplied as $\mathrm{Zn}\left(\mathrm{NO}_{3}\right)_{2}$.

plant species was as $\mathrm{Zn}$ (II). In addition, it is shown that XANES spectra of $\mathrm{Zn}$ in plant tissues are different from that of $\mathrm{ZnO}$ NPs, suggesting either an absence or a biotransformation of the NPs.

The Fourier transformed EXAFS for seedlings treated with $250 \mathrm{mg} \mathrm{kg}^{-1}$ of $\mathrm{Zn}^{2+}$ and $1600 \mathrm{mg}$ $\mathrm{kg}^{-1}$ of $\mathrm{ZnO}$ NPs are shown in Fig. 4, and the FEFF fittings of $\mathrm{Zn}$ in seedlings and $\mathrm{ZnO}$ NPs are shown in Table 3.

The FEFF fittings from seedling spectra and the model compounds $\mathrm{Zn}(\mathrm{OH})_{2}$ and $\mathrm{ZnO}$ suggested that $\mathrm{Zn}$ inside tissues was coordinated to six $\mathrm{O}$ and two $\mathrm{Zn}$ atoms. The $\mathrm{Zn}-\mathrm{O}$ interactions in samples were found between 1.86 and $2.06 \AA$, and $\mathrm{Zn}-\mathrm{Zn}$ interactions between 3.09 and $3.17 \AA$. This again suggests that $\mathrm{Zn}$ in tissues was not as ZnO NPs. These same findings have been reported for the desert species $P$. juliflora-velutina, $S$. tragus, and P. florida when they were germinated in ZnO NPs [19]. 

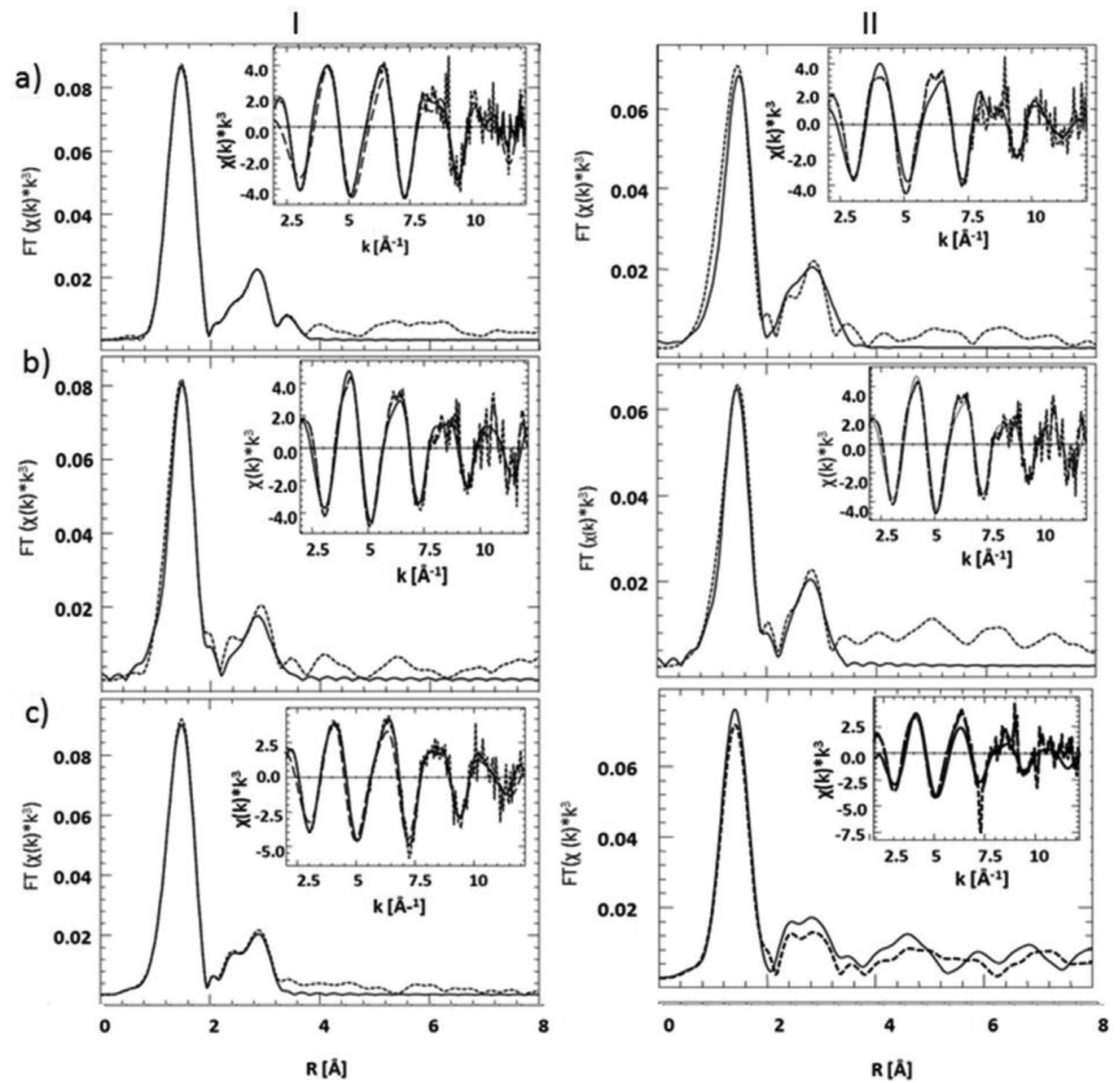

Fig. 4 Fourier transformed EXAFS from 2.0 to $12.2 \AA$ of the Zn taken up by seedlings germinated with (I) $250 \mathrm{mg}$ $\mathrm{L}^{-1} \mathrm{Zn}^{2+}$, and (II) $1600 \mathrm{mg} \mathrm{L}^{-1} \mathrm{ZnO}$ NPs. At the top right of each graph, the experimental $k^{3}$ EXAFS (dotted line), fitting (solid line), and back transform (dashed line) are shown. Lowercase letters indicate plant species (a) alfalfa, (b) tomato, and (c) cucumber.

Moreover, mesquite germinated in a free-NP media and transferred to a $\mathrm{ZnO}$ NP suspension, presented the same result [44] as $\mathrm{Zn}$ spectra resembles that of $\mathrm{Zn}\left(\mathrm{NO}_{3}\right)_{2}$. XAS studies of Datura innoxia plants treated with $\mathrm{Zn}$ ions have shown that $\mathrm{Zn}$ in tissues coordinated mainly to oxygen atoms from carboxylate groups of organic acids [45]. More recently, Salt and et al. [46] have reported that $\mathrm{Zn}$ (from $\mathrm{Zn}^{2+}$ ions) in the hyperaccumulator Thlasppi caerulescens accumulated in roots mainly coordinated with hystidine, while in shoot it was found as hydrated cation. The bulk XAS results from whole seedlings of the present study have shown that the three plant species store $\mathrm{Zn}$ in a very similar chemical structure regardless of the form (either as NP or an ion) in which $\mathrm{Zn}$ is fed. With the use of electron microprobe and confocal microscopy, Zhao et al. [47] have recently demonstrated that ZnO NPs enter into the xylem in corn. Thus, it is very likely that both $\mathrm{ZnO}$ NP storage and biotransformation occur in plants. Further microspectroscopy studies will provide additional information on this matter. 
Table 3 FEFF fittings of $\mathrm{ZnO}$ NPs and $\mathrm{Zn}$ in seedlings germinated with (a) $1600 \mathrm{mg} \mathrm{L}^{-1}$ of $\mathrm{ZnO} N P s$; and (b) $250 \mathrm{mg} \mathrm{L}^{-1}$ of $\mathrm{Zn}{ }^{2+}$ supplied as $\mathrm{Zn}\left(\mathrm{NO}_{3}\right)_{2}$.

\begin{tabular}{lcrrr}
\hline Sample & Interaction & $\mathrm{CN}$ & $\mathrm{R}(\AA)$ & $\sigma^{2}\left(\AA^{2}\right)$ \\
\hline $\mathrm{ZnO} N P$ s solid & $\mathrm{Zn}-\mathrm{O}$ & 4 & 1.95 & 0.0052 \\
& $\mathrm{Zn}-\mathrm{Zn}$ & 12 & 3.21 & 0.0100 \\
& $\mathrm{Zn}-\mathrm{Zn}$ & 9 & 3.76 & 0.0101 \\
\hline $\mathrm{Zn}\left(\mathrm{NO}_{3}\right)_{2}$-treated alfalfa seedlings & $\mathrm{Zn}-\mathrm{O}$ & 4 & 1.97 & 0.0020 \\
& $\mathrm{Zn}-\mathrm{O}$ & 2 & 1.86 & 0.0050 \\
& $\mathrm{Zn}-\mathrm{Zn}$ & 2 & 3.17 & 0.0071 \\
\hline $\mathrm{ZnO} \mathrm{NP}$-treated alfalfa seedlings & $\mathrm{Zn}-\mathrm{O}$ & 4 & 1.94 & 0.0074 \\
& $\mathrm{Zn}-\mathrm{O}$ & 2 & 1.88 & 0.0020 \\
\hline $\mathrm{Zn}\left(\mathrm{NO}_{3}\right)_{2}$-treated tomato seedlings & $\mathrm{Zn}-\mathrm{Zn}$ & 2 & 3.10 & 0.0097 \\
& $\mathrm{Zn}-\mathrm{O}-\mathrm{O}$ & 4 & 1.94 & 0.0049 \\
& $\mathrm{Zn}-\mathrm{Zn}$ & 2 & 2.09 & 0.0036 \\
\hline $\mathrm{ZnO} \mathrm{NP}$-treated tomato seedlings & $\mathrm{Zn}-\mathrm{O}$ & 4 & 1.90 & 0.0042 \\
& $\mathrm{Zn}-\mathrm{O}$ & 2 & 2.11 & 0.0098 \\
& $\mathrm{Zn}-\mathrm{Zn}$ & 2 & 3.16 & 0.0061 \\
\hline $\mathrm{Zn}\left(\mathrm{NO}_{3}\right)_{2}$-treated cucumber seedlings & $\mathrm{Zn}-\mathrm{O}$ & 4 & 1.88 & 0.0122 \\
& $\mathrm{Zn}-\mathrm{O}$ & 2 & 1.87 & 0.0055 \\
\hline $\mathrm{ZnO} \mathrm{NP}$-treated cucumber seedlings & $\mathrm{Zn}-\mathrm{Zn}$ & 1 & 3.16 & 0.0089 \\
\hline & $\mathrm{Zn}-\mathrm{O}-\mathrm{Zn}$ & 1 & 3.15 & 0.0082 \\
\hline
\end{tabular}

\section{CONCLUSIONS}

This study demonstrated that $\mathrm{ZnO}$ NPs affected seed germination of alfalfa and tomato. A $40 \%$ reduction in alfalfa germination was observed in seeds soaked in 800 and $1600 \mathrm{mg} \mathrm{L}^{-1}$ of $\mathrm{ZnO}$ NPs while a $20 \%$ germination reduction was observed in tomato seeds treated with $1600 \mathrm{mg} \mathrm{L}^{-1}$ of ZnO NPs. On the other hand, the percent germination of cucumber showed a significant increase in $\mathrm{ZnO}$ levels of 400 and $1600 \mathrm{mg} \mathrm{L}^{-1}$. Inhibitory concentrations of $50 \%\left(\mathrm{IC}_{50}\right)$ were observed in alfalfa and tomato seedlings treated with 800 and $1600 \mathrm{mg} \mathrm{L}^{-1}$ of $\mathrm{ZnO}$ NPs. Cucumber root seedlings were $170 \%$ larger than control roots when the seeds were soaked in $200 \mathrm{mg} \mathrm{L}^{-1}$ of $\mathrm{ZnO}$ NPs. Higher concentrations of NPs resulted in a reduction in biomass production in this plant species. $\mathrm{Zn}$ concentration in tissues increased as the external concentration of NPs increased. At $1600 \mathrm{mg} \mathrm{L}^{-1}$ of NPs, the concentration of $\mathrm{Zn}\left(\mathrm{mg} \mathrm{kg}^{-1} \mathrm{DW}\right)$ was: alfalfa $(4700)>$ tomato $(2100)>$ cucumber (1600). Differences in plant species is the reason for dissimilar $\mathrm{ZnO}$ uptake, tolerance, and NP toxicity. Bulk XAS analysis showed that it is very likely that $\mathrm{ZnO}$ NPs are biotransformed in plants. However, it is necessary to determine if the NPs were biotransformed on/in the root surface and to what extent this process occurred in the growth media.

\section{ACKNOWLEDGMENTS}

This material is based upon work supported by the National Science Foundation (NSF) and the EPA under Cooperative Agreement Number EF 0830117. Any opinions, findings, and conclusions or recommendations expressed in this material are those of the author(s) and do not necessarily reflect the 
views of the NSF or the EPA. This work has not been subjected to EPA review, and no official endorsement should be inferred. Jorge Gardea-Torresdey acknowledges the Dudley family for the Endowed Research Professorship in Chemistry, and portions of this research were carried out at the SSRL, a national user facility operated by Stanford University on behalf of the U.S. Department of Energy, Office of Basic Energy Sciences. The SSRL Structural Molecular Biology Program is supported by the Department of Energy, Office of Biological and Environmental Research, and by the National Institutes of Health, National Center for Research Resources, Biomedical Technology Program. The authors also acknowledge the USDA Grant Nos. 2008-38422-19138 and 2011-38422-30835 and the NSF Grant No. CHE-0840525. Guadalupe de la Rosa acknowledges Universidad de Guanajuato (DAIP-UG-051/11) and SEP-PROMEP.

\section{REFERENCES}

1. ASTM International. ASTM E2456-06, Standard Terminology Relating to Nanotechnology (2012).

2. K. Senthilkumar, O. Senthilkumar, K. Yamauchi, M. Sato, S. Morito, T. Ohba, M. Nakamura, Y. Fujita. Phys. Status Solidi B 246, 885 (2009).

3. S. Bubel, D. Nikolova, N. Mechau, H. Horst. J. Appl. Phys. 105, 64514 (2009).

4. R. Rajendran, C. Balakumar, H. A. Mohammed Ahammed, S. Jayakumar, K. Vaideki, E. M. Rajesh. Int. J. Eng. Sci. Technol. 2, 202 (2010).

5. C. Hanley, J. Layne, A. Punnoose, K. M. Reddy, I. Coombs, A. Coombs, K. Feris, D. Wingett. Nanotechnology 19, 295103 (2008).

6. R. D. Handy, R. Owen, E. Valsami-Jones. Ecotoxicology 17, 315 (2008).

7. B. Asiyanbola, W. Soboyejo. J Surg. Educ. 155 (2008).

8. A. Baun, N. B. Hartmann, K. Grieger, K. O. Kusk. Ecotoxicology 17, 387 (2008).

9. T. Xia, M. Kovochich, M. Liong, L. Madler, B. Gilbert, H. Shi, J. I. Yeh, J. I. Zink, A. E. Nel. ACS Nano 2, 2121 (2008).

10. L. Wang, L. Wang, W. Ding, F. Zhang. J. Nanosci. Nanotechnol. 10, 8617 (2010).

11. N. M. Franklin, N. J. Rogers, S. C. Apte, G. E. Batley, G. E. Gadd, P. S. Casey. Environ. Sci. Technol. 41, 8484 (2007).

12. H. Wang, R. L. Wick, B. Xing. Environ. Pollut. 157, 1171 (2009).

13. R. J. Griffitt, K. Hyndman, N. D. Denslow, D. S. Barber. Toxicol. Sci. 107, 404 (2009).

14. D. Lin, B. Xing. Environ. Pollut. 150, 243 (2007).

15. W. M. Lee, Y. J. An, H. Yoon, H. S. Kweon. Environ. Toxicol. Chem. 27, 1915 (2008).

16. D. Lin, B. Xing. Environ. Sci. Technol. 42, 5580 (2008).

17. P. Boonyanitipong, B. Kositsup, P. Kumar, S. Baruah, J. Dutta. Int. J. Biosci. Biochem. Bioinformatics 1, 282 (2011).

18. M. L. López-Moreno, G. De la Rosa, J. A. Hernández-Viezcas, J. Peralta-Videa, J. L. GardeaTorresdey. J. Agric. Food Chem. 58, 3689 (2010).

19. G. De la Rosa, M. L. López-Moreno, J. Hernández-Viezcas, J. R. Peralta-Videa, J. L. GardeaTorresdey. Int. J. Nanotechnol. 8, 492 (2011).

20. H. Xie, X. Nie, L. Li, C. Song. J. Wuhan Univ. Technol. 21, 28 (2006).

21. U.S. Environmental Protection Agency. Ecological Effects Test Guidelines (1996). http://www.docstoc.com/docs/46344080/8504100---Terrestrial-Plant-Toxicity-Tier-I-(SeedlingEmergence)-(PDF)

22. H. M. Kingston, L. B. Jassie (Eds.). Introduction to Microwave Sample Preparation, ACS Professional Reference Book Series, American Chemical Society, Washington, DC (1988).

23. T. Ressler. J. Synchrotron Radiat. 5, 118 (1998).

24. A. L. Ankudinov, B. Ravel, J. J. Rehr, S. D. Conradson. Phys. Rev. B 58, 7565 (1998).

25. B. D. Culity. Elements of X-ray Diffraction, $2^{\text {nd }}$ ed., Addison-Wesley, New York (1978).

(C) 2013, IUPAC

Pure Appl. Chem., Vol. 85, No. 12, pp. 2161-2174, 2013 
26. M. Auffan, J. Rose, M. R. Wiesner, J. Y. Bottero. Environ. Pollut. 157, 1127 (2009).

27. M. Di Salvatore, A. M. Carafa, G. Carratu. Chemosphere 73, 1461 (2008).

28. S. J. Klaine, P. J. J. Alvarez, G. E. Batley, T. F. Fernandes, R. D. Handy, D. Y. Lyon, S. Mahendra, M. J. McLaughlin, J. R. Lead. Environ. Toxicol. Chem. 27, 1825 (2008).

29. E. V. Seeger, A. Baun, M. Kastner, S. Trapp. J. Soils Sed. 9, 46 (2009).

30. T. J. Brunner, P. Wick, P. Manser, P. Spohn, R. N. Grass, L. K. Limbach, A. Bruinink, W. J. Stark. Environ. Sci. Technol. 40, 4374 (2006).

31. M. N. Al-Yemeni, A. A. Al-Helal. J. King Saud Univ. Sci. 15, 39 (2003).

32. S. Burca, M. Trifu, D. Cachita-Cosma. Biologia 27, 31 (1982).

33. N. Jain, G. D. Ascough, J. A. Van Staden. J. Plant Physiol. 165, 1422 (2008).

34. Y. Ozdener, H. G. Kutbay. Fresenius Environ. Bull. 18, 26 (2009).

35. A. A. El-Ghamery, M. A. El-Kholy, M. A. Abou El-Yousser. Mutat. Res. 537, 29 (2003).

36. E. J. Calabrese, L. A. Baldwin. Annu. Rev. Public Health 22, 15 (2001).

37. E. Navarro, A. Baun, R. Behra, N. B. Hartmann, J. Filser, A. J. Miao, A. Quigg, P. H. Santschi, L. Sigg. Ecotoxicology 17, 372 (2008).

38. T. Herren, U. Feller. J. Plant Physiol. 150, 228 (1997).

39. O. Atici, G. Agar, P. Battal. Biol. Plantarum 49, 215 (2005).

40. G. R. Rout, P. Das. Agronomie 23, 3 (2003).

41. F. Gao, C. Liu, C. Qu, L. Zhenh, F. Yang, M. Su, F. Hong. Biometals 21, 211 (2008).

42. P. Puzio, O. Blaesing, O. Thimm. Production of transgenic plants with an increased tolerance and/or resistance to environmental stress and increased biomass production by inactivating and/or repressing specific genes. Patent Application, WO 2008-EP56091 20080519 (2008).

43. A. Straczek, G. Sarret, A. Manceau, P. Hinsinger, N. Geoffroy, B. Jaillard. Environ. Exp. Bot. 63, 80 (2008).

44. J. A. Hernandez-Viezcas, H. Castillo-Michel, A. D. Servin, J. R. Peralta-Videa, J. L. GardeaTorresdey. Chem. Eng. J. 170, 346 (2011).

45. R. A. Kelly, J. C. Andrews, J. G. DeWitt. Microchem. J. 71, 231 (2002).

46. D. E. Salt, R. C. Prince, A. J. M. Baker, I. Raskin, I. J. Pickering. Environ. Sci. Technol. 33, 713 (2009).

47. L. Zhao, J. R. Peralta-Videa, M. Ren, A. Varela-Ramirez, C. Li, J. A. Hernandez-Viezcas, R. J. Aguilera, J. L. Gardea-Torresdey. Chem. Eng. J. 184, 1 (2012). 